\title{
GROWTH AND ALTERATION OF URANIUM-RICH MICROLITE
}

Reto Giere, R. J. Swope, Edgar Buck, Richard Guggenheim, Daniel Mathys, and Eric Reusser

\author{
Argonne National Laboratory \\ Chemical Technology Division \\ 9700 South Cass Avenue \\ Argonne, II 60439
}

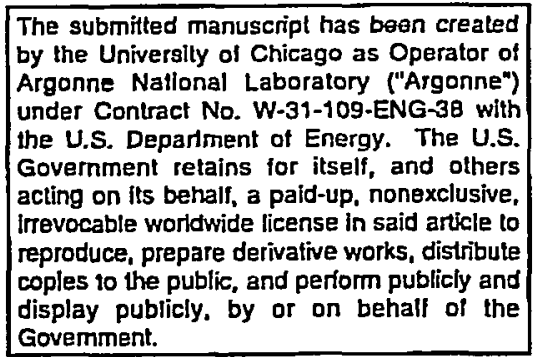

December 1999

This work is supported by the U.S. Department of Energy, under Contract W-31-109-ENG-58. 


\section{DISCLAIMER}

This report was prepared as an account of work sponsored by an agency of the United States Government. Neither the United States Government nor any agency thereof, nor any of their employees, make any warranty, express or implied, or assumes any legal liability or responsibility for the accuracy, completeness, or usefulness of any information, apparatus, product, or process disclosed, or represents that its use would not infringe privately owned rights. Reference herein to any specific commercial product, process, or service by trade name, trademark, manufacturer, or otherwise does not necessarily constitute or imply its endorsement, recommendation, or favoring by the United States Government or any agency thereof. The views and opinions of authors expressed herein do not necessarily state or reflect those of the United States Government or any agency thereof. 


\section{DISCLAIMER}

Portions of this document may be illegible in electronic image products. Images are produced from the best available original document. 
R. GIERÉ*, R. J. SWOPE*, E. C. BUCK**, R. GUGGENHEIM***, D. MATHYS***, and E. REUSSER *****

*Department of Earth and Atmospheric Sciences, Purdue University, West Lafayette, IN 479071397, USA; giere@purdue.edu

**Chemical Technology Division, Argonne National Laboratory, Argonne, II 60439, USA

***:SEM Laboratory, University of Basel, CH-4056 Basel, Switzerland

****Institute of Mineralogy and Petrography, ETH Zentrum, CH-8092 Zürich, Switzerland

\section{ABSTRACT}

Uranium-rich microlite, a pyrochlore-group mineral, occurs in 440 Ma old lithium pegmatites of the Mozambique Belt in East Africa. Microlite exhibits a pronounced growth zoning, with a U-free core surrounded by a U-rich rim $\left(\mathrm{UO}_{2}\right.$ up to 17 wt.\%). The core exhibits conjugate sets of straight cracks (cleavage planes) which provided pathways for a late-stage Uenriched pegmatitic fluid which interacted with the U-free microlite to produce a distinct $U$ enrichment along the cracks and led to the formation of the U-rich rim. Following the stage of U incorporation into microlite, a second generation of hydrothermal fluids deposited mica along the cleavage planes. Subsequent to these two hydrothermal stages, the host rock was uplifted and subjected to intense low-temperature alteration during which $\mathrm{Na}, \mathrm{Ca}$ and $\mathrm{F}$ were leached from the microlite crystals. This alteration also led to a hydration of microlite, but there is no evidence of U loss. These low-temperature alteration effects were only observed in the U-rich rim which is characterized by a large number of irregular cracks which are most probably the result of metamictization, as indicated by electron diffraction images and powder X-ray patterns.

\section{INTRODUCTION}

Pyrochlore-based ceramic waste forms are currently under development for the immobilization of excess weapons plutonium [1]. These ceramics are polyphase crystalline waste forms consisting of mainly pyrochlore and subordinate amounts of brannerite ( $\mathrm{UTi}_{2} \mathrm{O}_{6}$ ), zirconolite $\left(\mathrm{CaZrTi}_{2} \mathrm{O}_{7}\right)$, and rutile [2]. Minerals of the pyrochlore group conform to the simplified general formula

$$
\mathrm{A}_{2} \mathrm{~B}_{2} \mathrm{X}_{6} \mathrm{Y} \cdot \mathrm{nH}_{2} \mathrm{O} \text {, }
$$

where $A=\mathrm{Ca}, \mathrm{Na}$, actinides, rare earth elements (REE), $\mathrm{Ba}, \mathrm{Sr}, \mathrm{Bi}, \mathrm{Pb} ; B=\mathrm{Nb}, \mathrm{Ta}, \mathrm{Ti}$, $\mathrm{Zr}, \mathrm{Sb}, \mathrm{W}, \mathrm{Fe} ; X=\mathrm{O}, \mathrm{OH} ;$ and $Y=\mathrm{O}, \mathrm{OH}, \mathrm{F}$. On the basis of the B-site cations, three subgroups are commonly distinguished within the pyrochlore group [3]: (1) pyrochlore sensu stricto ( $\mathrm{Nb}$-rich), (2) microlite (Ta-rich), and (3) betafite (Ti-rich). A fourth subgroup, roméite (Sb-rich), was recently suggested by Brugger et al. [4]. Synthetic pyrochlore-group phases are also prominent actinide hosts in polyphase crystalline and certain glass-ceramic waste forms designed for the immobilization of high level nuclear waste $[5,6]$.

Pyrochlore and microlite are strategically important $\mathrm{Nb}$ and Ta ores. Pyrochlore and betafite are typical accessory minerals in carbonatites, and occur in various pegmatites, syenites and related alkaline rocks, and in some hydrothermal veins. Microlite is found primarily in granitic pegmatites, whereas roméite typically occurs in metamorphosed Mn deposits and hydrothermal veins $[4,7,8]$. The pyrochlore-group minerals provide excellent natural analogues for pyrochlore-based nuclear waste forms, because samples of variable age and with high actinide contents are available.

We have studied samples of microlite samples from Mozambique with scanning electron microscopy (SEM), electron probe microanalysis (EPMA), transmission electron microscopy (TEM), and powder X-ray diffractometry (XRD) to further our understanding of the growth and alteration of this actinide-bearing natural analogue mineral. 
The microlite specimens were first characterized optically with a polarizing petrographic microscope. Subsequently, polished thin sections $(30 \mu \mathrm{m}$ thick) were studied with an Environmental Scanning Microscope (Philips XL30 ESEM) using a field emission gun as electron source.

A portion of one of the large zoned microlite crystals was broken into $0.25 \mathrm{~mm}$ sized fragments which were carefully sorted by color and morphology into two samples: a core sample containing only fragments from the U-free center of the crystal, and a rim sample with only fragments from the U-rich rim. Each sample was finely powdered, mounted on a zero background Si plate (using acetone), and analyzed on a Scintag X2 automated powder X-ray diffractometer equipped with a Peltier solid-state detector using $\mathrm{Cu}-\mathrm{K} \alpha$ radiation at $45 \mathrm{kV}$ and 40 $\mathrm{mA}$. Data were collected from $2-70^{\circ} 2 \theta$ in step scan mode $\left(0.02^{\circ}\right.$ steps at $\left.10 \mathrm{~s} / \mathrm{step}\right)$.

Electron probe microanalysis was performed using a Cameca SX-50 microprobe which is equipped with four wavelength dispersive spectrometers and was operated at $20 \mathrm{kV}$ and a beam current of $20 \mathrm{nA}$ measured on a Faraday cage (beam size $\approx 2 \mu \mathrm{m}$ ). Samples and standards were coated with $200 \AA$ of carbon. Synthetic oxides were used as standards for all elements except for $\mathrm{Al}$ and $\mathrm{Fe}$, which were calibrated with mineral standards. For most elements, data collection time was $30 \mathrm{~s}$ on the peaks, and $15 \mathrm{~s}$ on background positions above and below the peaks. The raw data were corrected on-line by the PAP correction procedure [9].

For the transmission electron microscopy, microlite fragments were crushed between two clean glass slides. A small amount of alcohol was added and the particle-containing solution was pipetted onto lacy-carbon nickel grids. The samples were examined in a JEOL 2000 FXII TEM operated at $200 \mathrm{kV}$ with a $\mathrm{LaB}_{6}$ filament. Electron diffraction patterns were taken with a charge coupled device (CCD) camera which allows imaging at resolutions comparable to photographic film. Compositional analysis was performed using an IXRF Iridium II digital pulse processor with an attached Noran Instruments detector.

\section{RESULTS}

Microlite is a characteristic mineral in the early Paleozoic (approximately 500-450 Ma) lithium pegmatites of the Mozambique Belt in East Africa, where it occurs in association with albite, spodumene, lithian mica, potassium feldspar and quartz $[10,11]$. These pegmatites are strongly altered as a result of tropical weathering. However, microlite is resistant to weathering and is preserved as euhedral crystals in a clay mineral matrix which consists mainly of kaolinite.

We have examined Th-free microlite from an altered pegmatite which intruded into a greenschist country rock in the Mutala area, Alto Ligonha (Mozambique). Here, the euhedral microlite crystals have a vitreous luster and exhibit a pronounced growth zoning (Fig. 1), characterized by a light green U-free core which is surrounded by a brown U-rich rim containing up to 17 wt.\% $\mathrm{UO}_{2}$ (Fig. 2). The core exhibits conjugate sets of straight cracks which represent the octahedral cleavage of microlite. These cleavage planes provided pathways for a late-stage U-enriched pegmatitic fluid. This hydrothermal fluid interacted with the U-free microlite to produce a distinct $U$ enrichment along the cleavage planes (up to $5 \mathrm{wt} . \% \mathrm{UO}_{2}$; see Fig. 3 ) and led to the formation of the U-rich rim (500-600 $\mu \mathrm{m}$ thick; see Fig. 1). Following the stage of $U$ incorporation into microlite, late-stage hydrothermal fluids also deposited mica along the cleavage cracks. Subsequently, the crystals were further fractured, most probably as a result of decompression during uplift. During weathering under tropical conditions, groundwater penetrated these fractured crystals and led to the deposition of clay minerals along fractures and cleavage planes.

The excellent correlation between $\mathrm{PbO}$ and $\mathrm{UO}_{2}$ for all analyses representing unaltered microlite $\left(\mathrm{PbO}=0.033+0.051 * \mathrm{UO}_{2} ; \mathrm{n}=218, \mathrm{r}^{2}=0.959\right.$, root-mean square residual $\left.=0.060\right)$ indicates that $\mathrm{Pb}$ is almost entirely radiogenic and that the data can be used to estimate the age of formation. The calculations yielded an approximate chemical U-Pb age of $440 \mathrm{Ma}$ which is in good agreement with the chemical ages obtained from uraninite and monazite inclusions. These chemical ages allowed to calculate the cumulative alpha particle dose experienced by the microlite 


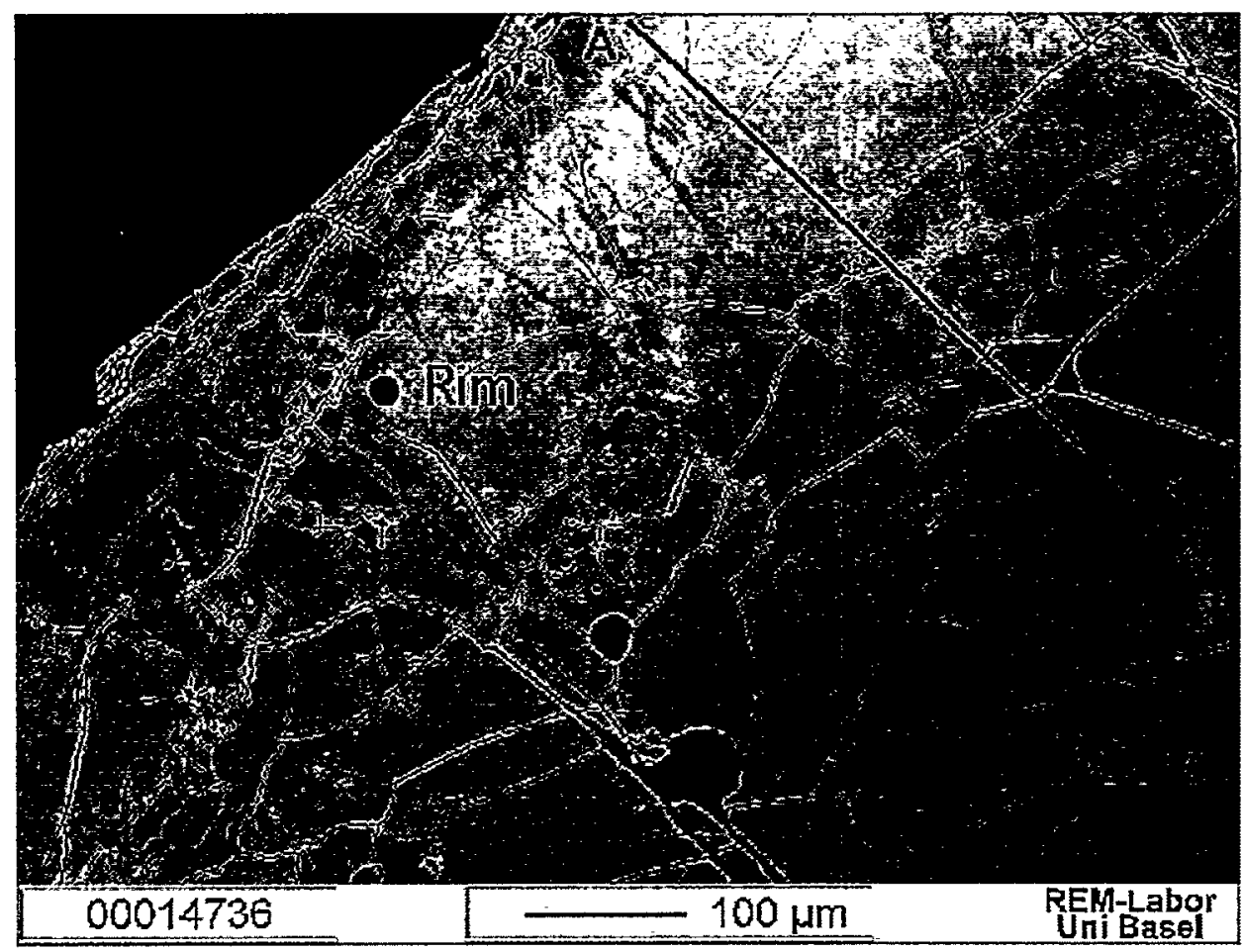

Figure 1: Backscattered electron image of microlite from Alto Ligonha, Mozambique. Note the abundant fractures which, in the rim area, are accompanied by dark alteration zones. Line A$\mathrm{B}$ shows the trace of the quantitative profile shown in Figure 2.

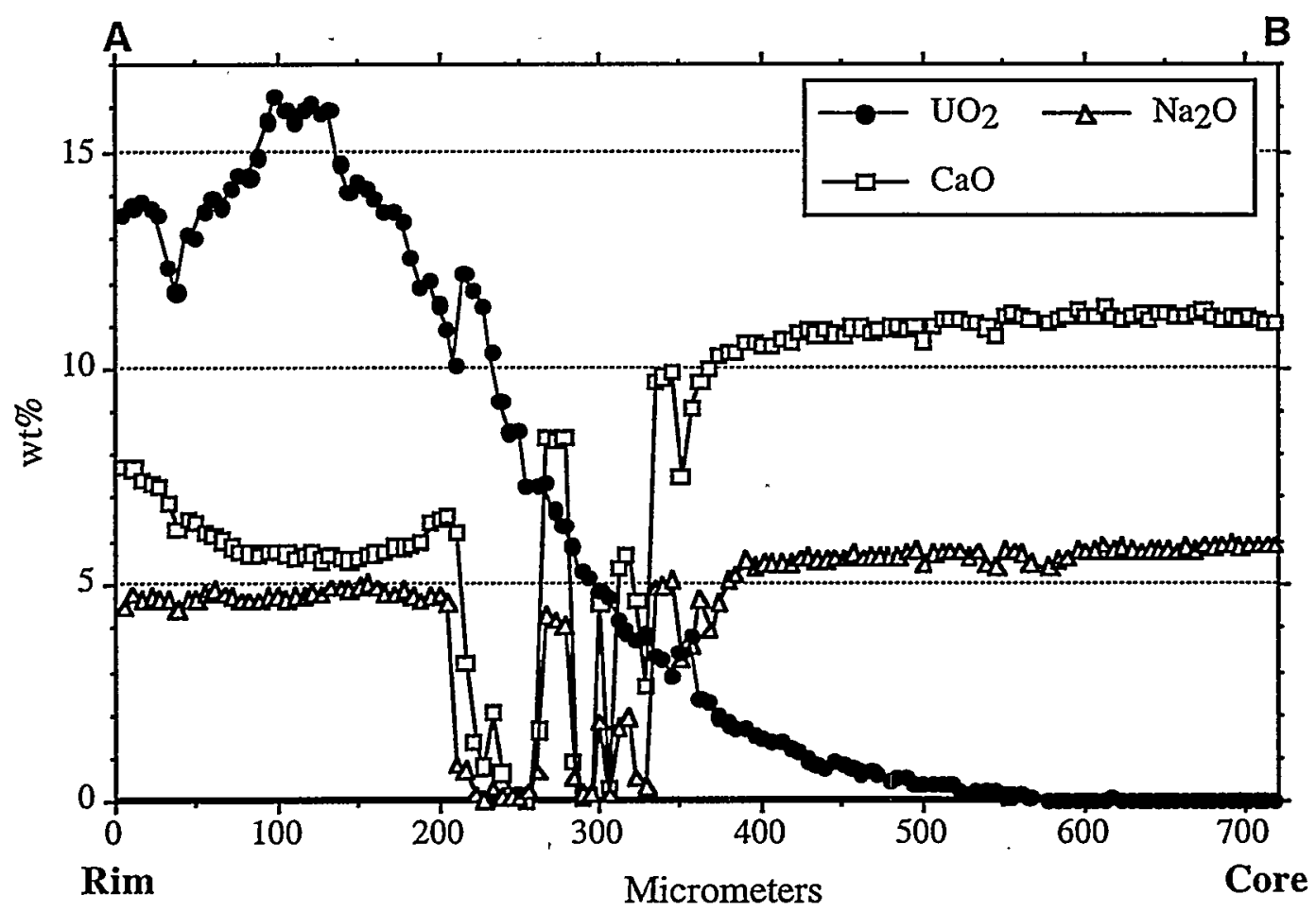

Figure 2: Concentration profile (EPMA data) across the rim into the core of microlite (profile trace shown in Fig. 1). Note that the trend for $\mathrm{UO}_{2}$ is smooth across the two alteration zones which are marked by the depletion in $\mathrm{Na}_{2} \mathrm{O}$ and $\mathrm{CaO}$. 


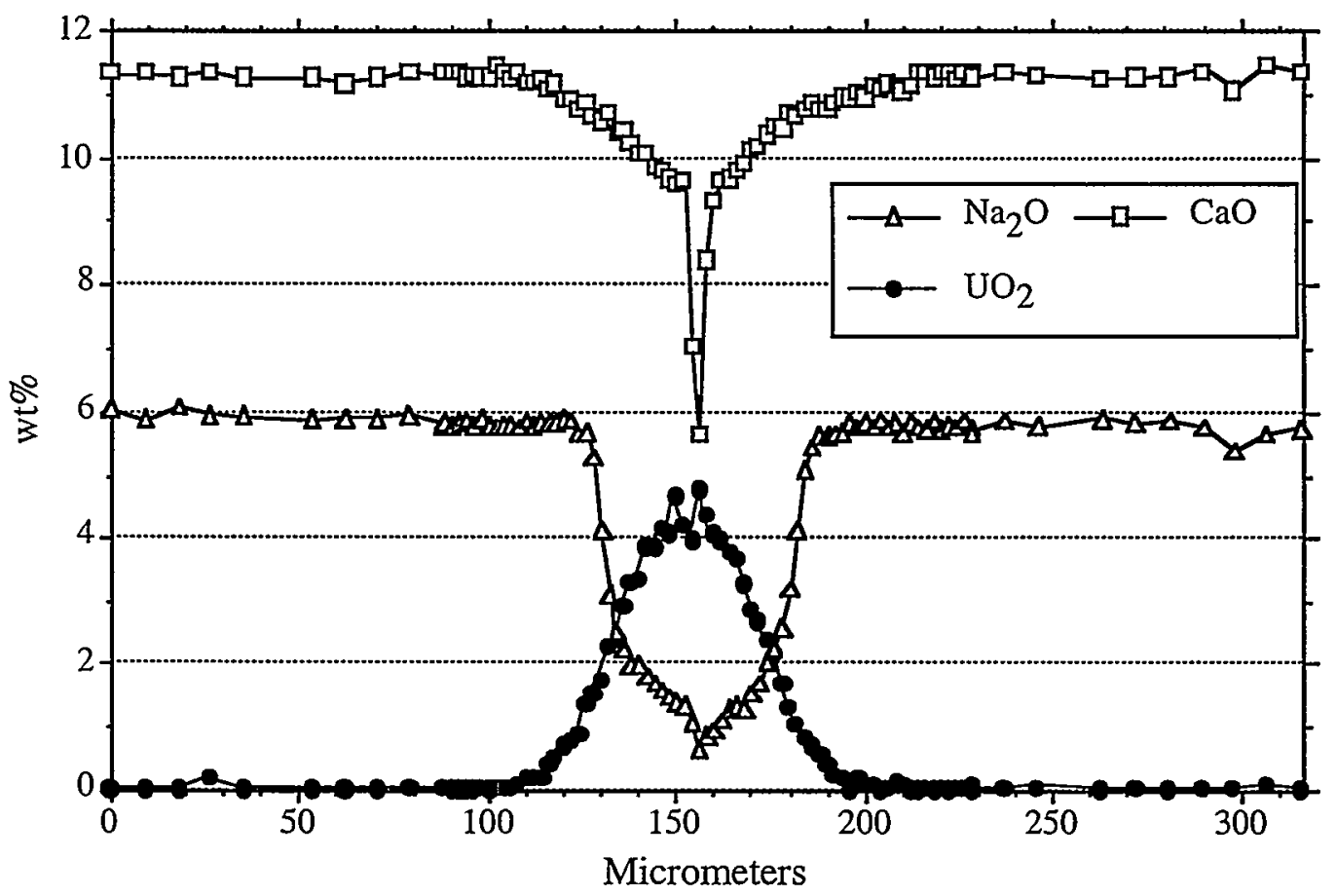

Figure 3: Concentration profile (EPMA data) across one of the cleavage cracks in the core of microlite. Note the symmetry with respect to the crack axis (located at 156 micrometers).

crystals as a result of the radioactive decay of U. In the U-rich rim, the maximum dose was approximately $2 * 10^{17}$ alphas $/ \mathrm{mg}$, suggesting that most of the U-rich rim should be completely metamict in the absence of annealing. This conclusion is based on previous studies which have shown that pyrochlore-group minerals become amorphous at a dose of $>10^{16}$ alphas $/ \mathrm{mg}[6$, 12 ], and is in agreement with preliminary TEM and XRD results. Our TEM investigations revealed the presence of diffuse rings in electron diffraction images, and these rings could be due to radiation damage microstructures resulting from alpha recoil collisions. The XRD patterns obtained for pulverized samples of the microlite core and rim areas demonstrate that the U-free core is completely crystalline, whereas the rim is almost entirely metamict (Fig. 4). The existence of some crystallinity (max. 5\% crystallinity) in the studied rim sample (Fig. 4) is likely the result of partial annealing [12].

Further evidence for the existence of the metamict state in the rim is provided by the occurrence of abundant microfractures (Fig. 5) which are observed in the U-rich rim only. Microfracturing commonly takes place as a result of the crystalline-to-amorphous transition which is associated with an isotropic volume increase of $\sim 5 \%$ in pyrochlore-group minerals [6, 12]. The fine cracks observed in the rim are arcuate and unevenly distributed, being particularly abundant around small inclusions of quartz and potassium feldspar. Backscattered electron images reveal that the U-rich rim of the studied microlites is strongly altered along these microfactures (Figs. 1, 5). Quantitative EPMA data demonstrate that this geochemical alteration is characterized by hydration (documented by low totals) and by a pronounced leaching of $\mathrm{Na}$, $\mathrm{Ca}$ and $\mathrm{F}$. At the same time, the data show that $\mathrm{U}$ was quantitatively retained during this alteration process (see Fig. 2) which most likely occurred under tropical weathering conditions. The chemical data demonstrate that the rate of $\mathrm{Na}, \mathrm{Ca}$ and $\mathrm{F}$ ion exchange of metamict microlite greatly exceeds the rate of total dissolution. These low-temperature alteration effects were not observed along the pervasive fractures in the U-free crystalline core, suggesting that the susceptibility of microlite to low-temperature alteration is directly related to the microstuctural damage caused by the alpha decay of U. 


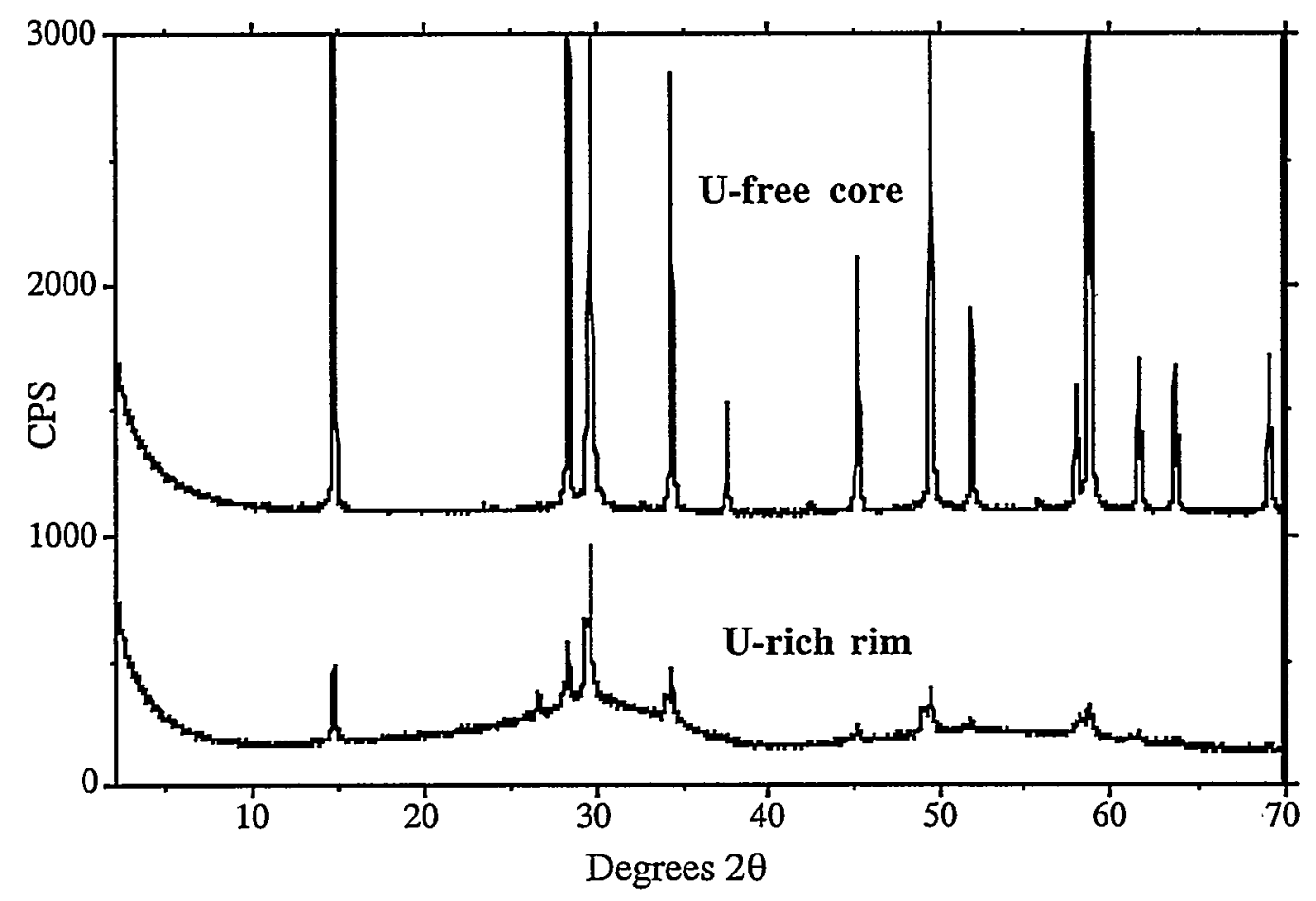

Figure 4: Powder X-ray diffraction patterns of the U-free core and the U-rich rim of microlite.

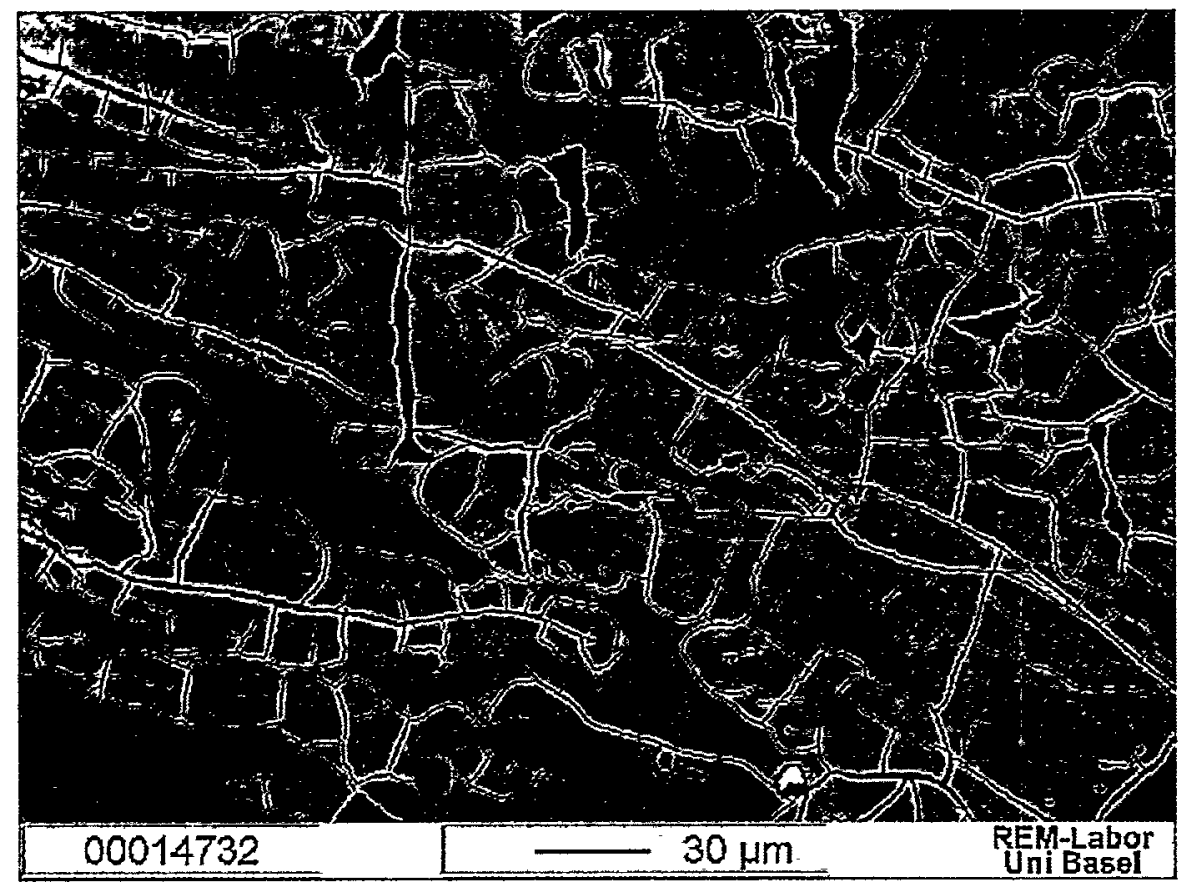

Figure 5: Backscattered electron image of an area within the U-rich rim. Note that microlite is altered (darker gray areas) along the abundant microfractures.

\section{DISCUSSION}

The results of this investigation demonstrate that $440 \mathrm{Ma}$ old crystals of U-rich microlite retain a high degree of physical integrity in temperature and pressure conditions that range from values typical of igneous environments to ambient (weathering) conditions. However, the chemical composition, does change in response to changing physical and chemical conditions. 
Alteration processes can be divided into primary (hydrothermal) and secondary (weathering) types [13-15]. These studies have shown that hydrothermal alteration takes place at relatively high temperatures (during late magmatic stages and the subsequent cooling) and probably before metamictization, whereas the weathering process usually occurs after the metamictization. The alteration process generally leads to dramatic changes in the A-site composition, but the concentration of actinides often remains remarkably constant. The results presented here are in perfect agreement with these observations. Additionally, our results demonstrate that only the metamict rim was significantly affected by the low-temperature alteration which had the following geochemical effects on the microlite composition: (1) hydration, (2) release of $\mathrm{Na}, \mathrm{Ca}$ and $\mathrm{F}$ to the environment, (3) localized redistribution of radiogenic $\mathrm{Pb}$, and (4) increase in the number of $\mathrm{A}$-site vacancies. However, despite the adverse conditions of tropical weathering, $U$ was retained during the alteration.

\section{CONCLUSIONS}

This natural analogue study documents that microlite is not only able to effectively scavenge $U$ from a fluid at elevated temperatures (pegmatite stage) but also to retain the element during low-temperature alteration under tropical weathering conditions.

Viewed from a different perspective, these results are, in our opinion, necessary to fully assess the long-term performance of pyrochlore-based nuclear waste forms. Our investigation emphasizes the importance of natural analogues for evaluating the durability of waste form materials over geologic time spans and under natural conditions.

\section{REFERENCES}

1. E.R. Vance, C.J. Ball, R.A. Day, K.L. Smith, M.G. Blackford, B.D. Begg, and P.J. Angel, J. Alloys Comp. 213/214, 406 (1994).

2. E.C. Buck, D.B. Chamberlain, and R. Gieré, in Scientific Basis for Nuclear Waste Management XXII, edited by D.J. Wronkiewicz and Lee. J.H. (Mater. Res. Soc. Proc. 556, Pittsburgh, PA 1999), p. 19-26.

3. D.D. Hogarth, Am. Mineral. 62, 403 (1977).

4. J. Brugger, R. Gieré, S. Graeser, and N. Meisser, Contrib. Mineral. Petrol. 127, 136 (1997).

5. A.B. Harker, in Radioactive Waste Forms for the Future, edited by W. Lutze and R.C. Ewing, North-Holland, Amsterdam, 1988, pp. 335-392.

6. R.C. Ewing, W.J. Weber, and F.W. Clinard, Progr. Nucl. Energy 29(2), 63 (1995).

7. P. Cerny and T.S. Ercit, in Lanthanides, tantalum and niobium, edited by P. Möller, P. Cerny, and F. Saupé, Springer, Berlin, 1989, pp. 27-79.

8. G.R. Lumpkin and R.C. Ewing, in Scientific Basis for Nuclear Waste Management VIII, edited by C.H. Jantzen, J.A. Stone, and R.C. Ewing (Mater. Res. Soc. Proc. 44, Pittsburgh, PA 1985), p. 647-654.

9. J.L. Pouchou and F. Pichoir, Rech. Aérosp. 1984-3, 167 (1984).

10. J.M. Correia Neves, J.E. Lopes Nunes, and D.B. Lucas, Rev. Ciênc. Geol., Lourenço Marques, Série A 4, 35 (1971).

11. O. Von Knorring and A. Fadipe, Bull. Minéral. 104, 496 (1981).

12. G.R. Lumpkin and R.C. Ewing, Phys. Chem.Minerals 16, 2 (1988).

13. G.R. Lumpkin and R.C. Ewing, Am. Mineral. 77, 179 (1992).

14. G.R. Lumpkin and R.C. Ewing, Am. Mineral. 80, 732 (1995).

15. G.R. Lumpkin and R.C. Ewing, Am. Mineral. 81, 1237 (1996). 